\title{
KEMAMPUAN MENGONSTRUKSI TEKS LAPORAN HASIL OBSERVASI SISWA KELAS X SMA NEGERI 7 MEDAN \\ TAHUN PEMBELAJARAN 2016/2017
}

\author{
Oleh \\ Sri Juliana Larosa \\ Fitriani Lubis, S.Pd.,M.Pd.
}

\begin{abstract}
Penelitian ini bertujuan untuk mengetahui dan mendeskripsikan kemampuan mengonstruksi teks laporan hasil observasi oleh siswa kelas X SMA Negeri 7 Medan tahun pembelajaran 2016/2017. Populasi penelitian ini adalah seluruh siswa kelas X SMA Negeri 7 Medan tahun pembelajaran 2016/2017 yang terdiri dari 8 kelas dan berjumlah 309 orang. Sampel penelitian ini diambil dengan cara random sampling. Sampel penelitian diambil $20 \%$ dari populasi sehingga sampel penelitian ini adalah 62 orang siswa.Metode yang digunakan dalam penelitian ini adalah metode deskriptif kualitatif, yaitu mendeskripsikan suatu keadaan alamiah mengenai kegiatan mengonstruksi teks laporan hasil observasi siswa kelas X SMA Negeri 7 Medan. Instrumen yang digunakan untuk memperoleh data adalah tes essay. Data penelitian menunjukkan bahwa kemampuan siswa dalam mengonstruksi teks laporan hasil observasi memiliki nilai rata-rata (mean) 78,87 dan berada pada kategori baik. Hal ini dapat dilihat dari rentang nilai 86100 dengan kategori sangat baik diperoleh sebanyak 15 orang $(24,19 \%)$, rentang nilai 76-85 dengan kategori baik diperoleh sebanyak 24 orang (38.71\%), rentang nilai 56-75 dengan kategori cukup diperoleh sebanyak 20 orang $(32,25 \%)$, rentang nilai 10-55 dengan kategori kurang diperoleh sebanyak 3 orang $(4,83 \%)$. Berdasarkan analisis data diatas maka dapat disimpulkan bahwa kemampuan mengonstruksi teks laporan hasil observasi pada siswa kelas X SMA Negeri 7 Medan Tahun Pembelajaran 2016/2017 termasuk dalam kategori baik.
\end{abstract}

Kata kunci: kemampuan, mengonstruksi, teks laporan hasil observasi

\section{PENDAHULUAN}

Bahasa Indonesia merupakan suatu bentuk alat komunikasi dan sebagai alat pemersatu bangsa.Bahasa Indonesia juga merupakan salah satu hasil kebudayaan yang harus dipelajari dan diajarkan. Pengajaran bahasa Indonesia pada hakikatnya merupakan salah satu sarana mengupayakan pembinaan dan pengembangan bahasa Indonesia secara terarah. Maka dari itu proses pengajaran bahasa Indonesia diharapkan siswa 
mempunyai kemampuan yang memadai untuk menggunakan bahasa Indonesia secara baik dan benar.

Belajar berbahasa merupakan belajar berkomunikasi.Pembelajaran bahasa juga ditujukan untuk menumbuhkan kebanggaan dalam berbahasa.Namun, dewasa ini para siswa kurang memiliki motivasi untuk menggunakan bahasa Indonesia. Karena kurang memiliki motivasi maka kebanggaan menggunakan bahasa Indonesia juga menurun, bahkan implikasinya terasa dalam pencapaian hasil belajar rendah. Kondisi ini memerlukan pikiran-pikiran baru (kreatif) dalam pembelajaran bahasa sehingga kebanggaan berbahasa Indonesia menjadi tumpuan bangsa Indonesia kelak.

Komponen yang mempengaruhi proses pembelajaran adalah siswa, guru, tujuan pembelajaran, materi, strategi, media dan pendekatan serta evaluasi. Jika salah satu komponen tersebut kurang maksimal, maka pengaruhnya adalah proses pembelajaran pun menjadi kurang maksimal pula. Kreativitas guru dalam menyampaikan materi yang dibawakan serta penggunaan media atau strategi sangat berpengaruh terhadap ketertarikan siswa dalam belajar.

Pembelajaran Bahasa Indonesia dalam kurikulum 2013, siswa diharapkan mampu menngonstruksi dan menggunakan teks sesuai dengan tujuan dan fungsi sosialnya. Dalam pembelajaran bahasa berbasis teks, bahasa Indonesia diajarkan bukan sekadar sebagai pengetahuan bahasa, melainkan sebagai teks yang mengemban fungsi untuk menjadi sumber aktualisasi diri penggunanya pada konteks sosial-budaya akademis. Teks dimaknai sebagai satuan bahasa yang mengungkapkan makna secara kontekstual.

Permendikbud Nomor 69 Tahun 2013 memuat tentang kurikulum 2013 yang dirancang guna mempersiapkan manusia Indonesia agar memiliki kemampuan hidup sebagai pribadi dan warga negara yang beriman, produktif, kreatif, inovatif, dan afektif serta mampu berkontribusi pada kehidupan bermasyarakat, berbangsa, bernegara, dan peradaban dunia. Kurikulum 2013 berusaha mengembangkan keseimbangan antara pengembangan sikap spiritual dan sosial, rasa ingin tahu, kreativitas, dan bekerjasama dengan kemampuan intelektual dan psikomotorik.Selain itu, kurikulum ini juga 
berusaha mengembangkan sikap, pengetahuan, dan keterampilan peserta didik serta menerapkannya dalam berbagai situasi di sekolah dan masyarakat.

Kurikulum 2013 memenuhi dua dimensi kurikulum.Pertama adalah rencana dan pengaturan mengenai tujuan, isi, dan bahan pelajaran. Kedua adalah cara yang digunakan untuk kegiatan pembelajaran. Hal ini sesuai dengan pedoman dalam penyelenggaraan pendidikan yang terdiri atas berbagai standar sebagai acuan dalam pembelajaran. Standar-standar itu meliputi Standar Kompetensi Lulusan (SKL), Standar Isi, Standar Proses, Standar Penilaian, Kompetensi Inti, dan Kompetensi Dasar.

Standar Proses Pendidikan Dasar dan Menengah telah mengisyaratkan tentang perlunya proses pembelajaran yang dipadu dengan kaidah-kaidah pendekatan saintifik/ilmiah yang diterapkan kedalam model pembelajaran yang sesuai dengan materi pembelajarannya. Pendekatan ini dimulai dari kegiatan mengamati, menanya, mengumpulkan informasi, mengolah informasi, dan akhirnya mengomunikasikan.

Salah satu hal yang menarik dari penerapan Kurikulum 2013 ini adalah materi pembelajarannya.Berbagai jenis teks dengan tujuan sosial, struktur, dan ciri bahasa dipelajari pada Kurikulum 2013.Salah satunya teks laporan hasil observasi. Teks laporan hasil observasi dalam pembelajaran Bahasa Indonesia di kelas $\mathrm{X}$ bertujuan untuk melatih siswa berpikir kritis dan kreatif dalam menyelesaikan permasalahan dalam kehidupan nyata dengan cara yang unik dan lebih baik. Selain dari segi materi, Kurikulum 2013 menuntut siswa untuk lebih berperan aktif selama kegiatan pembelajaran.Dalam menciptakan pembelajaran yang efektif, guru dituntut untuk kreatif dan inovatif.Kurikulum 2013 juga menuntut diterapkannya pendekatan saintifik.Oleh karena itu, guru harus mendorong siswa untuk aktif selama pembelajaran berlangsung.

Salah satu kompetensi dasar (KD) dalam pembelajaran bahasa Indonesia di kelas $\mathrm{X}$ adalah mengonstruksi teks laporan hasil observasi dengan memperhatikan isi dan aspek kebahasaan (KD 4.2). Dalam mengonstruksi sebuah teks, siswa harus mampu memahami isi, struktur, dan ciri kebahasaan teks dengan cara melakukan pengamatan, penggolongan, lalu siswa harus dapat menjelaskan serta mengambil simpulan dari hasil yang mereka konstruksi. 
Berdasarkan penelitian sebelumnya yang dilakukan Jainab Arifin SMP Negeri 4 Gorontalo dengan judul jurnal "Kemampuan Menyusun Teks Hasil Observasi dalam Pembelajaran Bahasa Indonesia Berdasarkan Kurikulum 2013 pada siswa kelas VII SMP Negeri 4 Gorontalo Tahun Pelajaran 2014/2015." Perolehan hasil penilaian mengonstruksi rata-rata nilai 60, sedangkan KKM adalah 75.

Adinda Karina (2016) dalam penelitiannya yang berjudul "Hubungan Pemahaman Isi, Struktur, dan Ciri Kebahasaan terhadap Kemampuan Menulis Teks Laporan Hasil Observasi Oleh Siswa Kelas X SMA Negeri 2 Kabanjahe Tahun Pembelajaran 2015/2016." Perolehan hasil penilaian rata - rata nilai 79,03 dan tergolong sangat baik. Persamaan penelitian ini dengan penelitian yang dilakukan oleh Adinda Karina (2016), yaitu sama-sama bertujuan ingin melihat kemampuan siswa dalam menulis teks laporan hasil observasi.Selain itu, perbedaan penelitian ini dengan Adinda Karina (2016), yaitu masalah yang dikaji.

Selain itu, berdasarkan hasil wawancara dengan guru mata pelajaran Bahasa Indonesia di SMA Negeri 7 Medan hasil belajar mengonstruksi teks laporan hasil observasi siswa berada pada kategori cukup dengan nilai rata-rata 65 sedangkan KKM adalah 75 .

Fakta menunjukkan bahwa pembelajaran mengonstruksi teks laporan hasil observasi di SMA Negeri 7 Medan belum menampakkan adanya keberhasilan karena masih jauh dari harapan.Siswa memiliki kemampuan menuangkan ide dan gagasan menjadi sebuah karangan masih rendah.

Berdasarkan latar belakang di atas, perlu kiranya dilakukan suatu penelitian untuk melihat bagaimana kemampuan siswa dalam mengonstruksi teks laporan hasil observasi.Dalam hal ini, masalah yang ditawan untuk menaungi penelitian ini adalah "Kemampuan Mengonstruksi Teks Laporan Hasil Observasi Siswa Kelas X SMA Negeri 7 Medan Tahun Pembelajaran 2016/2017.” 


\section{KEMAMPUAN MENGONSTRUKSI TEKS LAPORAN HASIL OBSERVASI}

Teks laporan hasil observasi adalah teks yang menjelaskan informasi mengenai sesuatu, baik itu hewan, tumbuhan, alam, fenomena sosial, hasil karya manusia, dan/atau fenomena alam sesuai fakta dengan klasifikasi kelas dan subkelas yang ada di dalamnya berdasarkan hasil observasi yang telah dilakukan.

Menurut Priyatni (2015: 76) "Teks yang menyampaikan informasi tentang sesuatu apa adanya sebagai hasil pengamatan dan analisis secara sistematis disebut dengan teks laporan hasil observasi. Teks laporan hasil observasi bertujuan untuk menginformasikan kondisi objektif sesuatu yang di amati dan di analisis secara sistematis, tidak di bumbui dengan respons pribadi tentang objek yang di laporkan tersebut." Menurut Darmawati (2016: 3) "Teks laporan hasil observasi (report) berisi penjabaran umum mengenai sesuatu yang didasarkan pada hasil kegiatan observasi. Kegiatan observasi merupakan kegiatan pengumpulan data atau informasi melalui pengamatan langsung atau peninjauan secara cermat di lapangan atau lokasi pengamatan.Teks laporan ini menyampaikan informasi apa adanya sebagai hasil pengamatan yang sistematik dan berdasarkan fakta."Sedangkan menurut Kosasih (2014: 43) "Teks laporan hasil observasi adalah teks yang mengemukakan fakta-fakta yang diperoleh melalui pengamatan.Dengan teks tersebut, pembaca memperoleh sejumlah pengetahuan ataupun wawasan, bukan hasil imajinasi."

Berdasarkan uraian di atas dapat disimpulkan bahwa teks laporan hasil observasi adalah sebuah teks yang memaparkan hasil observasi secara sistematik dan objektif berdasarkan kenyataan atau fakta yang ada.Teks jenis ini juga mendeskripsikan mengenai bentuk, ciri, dan/atau sifat umum suatu objek.Objek tersebut dapat berupa manusia, benda, hewan, tumbuhan, atau berbagai peristiwa yang terjadi di dunia ini.

Kemampuan mengonstruksi teks laporan hasil observasi merupakan kemampuan untuk memahami dan mengetahui teks laporan hasil observasi dengan isi, struktur, dan ciri kebahasaan dari teks tersebut.Teks ini berisi penjabaran umum mengenai sesuatu yang didasarkan pada hasil kegiatan observasi.Kegiatan observasi merupakan kegiatan pengumpulan data atau informasi melalui pengamatan langsung atau peninjauan secara cermat di lapangan atau lokasi pengamatan.Kegiatan ini dilakukan untuk memperoleh 
informasi tentang tingkah laku, keadaan, kondisi, atau situasi dari objek yang diteliti.Kemudian, peneliti mencatat setiap keadaan yang diamati. Teks laporan ini menyampaikan informasi apa adanya sebagai hasil pengamatan yang sistematik dan berdasarkan fakta.

Kemampuan mengonstruksi teks laporan hasil observasi ini sangat penting, karena mengonstruksi teks laporan hasil observasi termasuk salah satu kompetensi yang harus dicapai siswa dalam kurikulum 2013.Tolok ukurnya yaitu sudah mampukah siswa mengonstruksi sebuah teks laporan hasil observasi dengan pemahaman isi, struktur, dan ciri kebahasaan yang dimilikinya.

Berdasarkan penjelasan tersebut, dapat disimpulkan bahwa yang akan diteliti dalam penelitian ini adalah kemampuan siswa dalam mengonstruksi teks laporan hasil observasi.

\section{METODE PENELITIAN}

Sukmadinata (2012: 52) menyatakan bahwa, "Metode penelitian merupakan rangkaian cara atau kegiatan pelaksanaan penelitian yang didasari oleh asumsi-asumsi dasar, pandangan - pandangan filosofis dan ideologis, pertanyaan dan isu-isu yang dihadapi." Maka dalam penelitian ini, penulis menggunakan metode kualitatif deskriptif, yaitu suatu metode yang berusaha menggambarkan situasi atau gejala yang terjadi dalam keadaan nyata. Dalam penelitian kualitatif deskriptif, peneliti tidak melakukan manipulasi atau memberi perlakuan-perlakuan tertentu terhadap variabel, tetapi semua kegiatan, keadaan, kejadian, aspek komponen atau variabel berjalan apa adanya. Penemuan makna adalah fokus dari keseluruhan proses yang akan dilakukan.

Dari pernyataan di atas, menjadi alasan penulis menggunakan metode ini, dengan tujuan untuk melihat kemampuan siswa dalam mengonstruksi teks laporan hasil observasi.

\section{HASIL PENELITIAN DAN PEMBAHASAN}

\section{Hasil Penelitian}


Data penelitian ini diolah dengan menggunakan teknik statistik deskripsi.Pengolahan data penelitian mengonstruksi teks laporan hasil observasi dilakukan dengan tahapan menghitung nilai rata-rata (mean) kemudian mempresentasekan nilai kemampuan dengan menyusun tabel frekuensi data.

Nilai rata-rata kemampuan mengonstruksi teks laporan hasil observasi siswa kelas X SMA Negeri 7 Medan adalah sebagai berikut.

$$
\begin{aligned}
& M=\frac{\sum X \boldsymbol{X}}{\boldsymbol{N}} \\
& =\underline{4890} \\
& 62 \\
& \quad=78,87
\end{aligned}
$$

Keterangan:

$\mathrm{M} \quad$ = rata-rata nilai

$\mathrm{N} \quad=$ jumlahsiswa

$\sum X i=$ jumlahnilaiseluruhsiswa

Kemudian skor rata-rata ini dikonfirmasikan dengan kategori penilaian untuk skala empat yang dikemukakan oleh Sudijono (2007:24) sebagaiberikut.

\begin{tabular}{|c|c|c|}
\hline No & Skor & KategoriNilai \\
\hline 1 & $86-100$ & SangatBaik \\
\hline 2 & $76-85$ & Baik \\
\hline 3 & $56-75$ & Cukup \\
\hline 4 & $10-55$ & Kurang \\
\hline
\end{tabular}

Berdasarkan skor rata-rata yang diperoleh yaitu 78,87 dan setelah dibulatkan menjadi 79 dan setelah dikonfirmasikan dengan peringkat nilai kategori maka dapat disimpulkan bahwa kemampuan mengonstruksi teks laporan hasil observasi oleh siswa kelas X SMA Negeri 7 Medan tahun pembelajaran 2016/2017 adalah baik. Dengan kata lain, siswa mampu mengonstruksi teks laporan hasil observasi berdasarkan keseluruhan aspek yakni, isi, struktur, dan ciri kebahasaan teks laporan hasil observasi. 


\section{Pembahasan Hasil Penelitian}

Berdasarkan hasil penelitian, diketahui bahwa kemampuan mengonstruksi 54 laporan hasil observasi oleh siswa kelas X SMA Negeri Medan Tahun Pembelajaıaı 2016/2017 dengan skor rata-rata 79, dikategorikan baik.

Ada tiga aspek yang dinilai dalam kemampuan mengonstruksi teks laporan hasil observasi, yaitu aspek isi, struktur, dan ciri kebahasaan. Berdasarkan penelitian yang telah dilakukan, aspek isi dan aspek struktur yakni aspek isi memperoleh nilai 90 dan aspek struktur memperoleh nilai 89, kedua aspek ini berada pada kategori sangat baik. Sedangkan aspek ciri kebahasaan memperoleh nilai 60 yang berada pada kategori cukup.Hal ini menunjukkan bahwa siswa lebih mampu mengonstruksi teks laporan hasil observasi berdasarkan isi dan struktur dibandingkan dengan ciri kebahasaan.Dikarenakan siswa dalam menguasai ciri kebahasaan dalam sebuah teks masih tidak memperdulikan kata-kata teknis, kopula, kata benda, kata kerja, kata yang menyatakan pengelompokan, kata yang menyatakan perbedaan.Hal inilah yang harus ada dalam teks laporan hasil observasi.Untuk mengatasai hal tersebut, sebaiknya guru lebih sering mengingatkan siswa mengenai ciri kebahasaan.

Aspek isi dalam teks laporan hasil observasi memperoleh nilai 90 yang berada pada kategori sangat baik.Hal ini menunjukkan bahwa kemampuan siswa dalam mengonstruksi teks laporan hasil observasi sudah mampu menulis teks laporan hasil observasi yang memiliki topik, sesuai dengan fakta dan informatif dengan baik.

Aspek struktur dalam teks laporan hasil observasi memperoleh nilai 89 yang berada pada kategori sangat baik.Hal ini menunjukkan bahwa siswa mampu menulis teks laporan hasil observasi sesuai dengan struktur dan runtut.

\section{PENUTUP}

Berdasarkan hasil penelitian dan pembahasan mengenai kemampuan mengonstruksi teks laporan hasil observasi oleh siswa kelas X SMA Negeri 7 Medan Tahun Pembelajaran 2016/2017, maka dapat disimpulkan bahwa kemampuan 
mengonstruksi teks laporan hasil observasi oleh siswa kelas X SMA Negeri 7 Medan Tahun Pembelajaran 2016/2017 berada dalam kategori baik dengan perolehan nilai ratarata 79.Dari 62 siswa yang dijadikan sampel sebanyak 15 (24\%) siswa berada pada rentang skor 86-100 termasuk dalam kategori sangat baik.Kemudian sebanyak 24 (39\%) siswa berada pada rentang skor 76-85 termasuk dalam kategori baik.Berikutnya, sebanyak $20(32 \%)$ siswa berada pada rentang skor 56-75 termasuk dalam kategori cukup.Dan sebanyak 3 (5\%) siswa yang berada pada rentang skor 55-0 dalam kategori kurang.

Berdasarkan analisis penilaian pada aspek-aspek yang berkaitan dengan kemampuan mengonstruksi teks laporan hasil observasi oleh siswa kelas X SMA Negeri 7 Medan Tahun Pembelajaran 2016/2017, ditemukan bahwa aspek isi memperoleh nilai rata-rata 90 berada dalam kategori sangat baik, aspek struktur memperoleh nilai ratarata 89 berada dalam kategori sangat baik, sedangkan aspek ciri kebahasaan memperoleh nilai rata-rata 60 berada dalam kategori cukup, aspek ciri kebahasaan perlu mendapatkan perlakuan khusus.

\section{DAFTAR PUSTAKA}

Salinan Permendikbud No.69 Tahun 2013 tentang Kerangka Dasar dan Struktur Kurikulum SMA/Aliyah.

Sudijono, Anas. 2007. Pengantar Statistika Pendidikan. Jakarta: Raja Grafindo Persada. Sukmadinata, Nana Syaodih. Metode Penelitian Pendidikan. Bandung: PT. Remaja Rosdakarya.

Kosasih, H.E. 2014. Jenis - jenis Teks Analisis Fungsi, Struktur, dan Kaidahnya serta Langkah Penulisannya. Bandung: Yrama Widya.

Priyatni, Endah Tri. 2015. Desain Pembelajaran Bahasa Indonesia dalam Kurikulum 2013. Jakarta: Bumi Aksara.

Darmawati, Uti. 2016. Bahasa Indonesia Mata PelajaranWajib. Klaten: PT. Intan Pariwara 